\title{
An uncommon cause of pneumobilia: blunt abdominal trauma
}

\author{
Nadir bir pnömobili nedeni: Künt karın travması
}

\author{
Fahrettin YILDIZ, ${ }^{1}$ Sacit ÇOBAN, ${ }^{2}$ Alpaslan TERZİ, ${ }^{1}$ Hasan CECE, ${ }^{3}$ Ali UZUNKOY ${ }^{1}$
}

\begin{abstract}
Pneumobilia is described as occurrence of free air in the gallbladder or biliary tree. There are a number of causes of pneumobilia, including surgically created biliary enteric fistula, instrumentation of the bile duct on endoscopic retrograde cholangiopancreatography, emphysematous cholecystitis, and pyogenic cholangitis. Pneumobilia has also occurred following blunt abdominal trauma, but to date, no more than five cases of such injury have been reported in the literature. In this report, we present a patient struck by a motor vehicle with traumatic pneumobilia following blunt trauma to the abdomen, which was managed conservatively.
\end{abstract}

Key Words: Abdomen; blunt trauma; pneumobilia.
Pnömobili safra kesesinde veya safra yollarında hava oluşması olarak tanımlanır. Pnömobilinin birçok nedeni vardır ve bunlar arasında cerrahi olarak oluşturulmuş biliyoenterik fistüller, endoskopik retrograt kolanjiopankreatografide safra yollarına girilmesi, anfizamatöz kolesistit ve piyojenik kolanjit yer almaktadır. Künt karın travması sonrasında da pnömobili gelişebileceği bildirilmiştir. Fakat bu sayı günümüze kadar beş olguyu geçmemektedir. $\mathrm{Bu}$ yazıda, motorlu taşıt çarpması sonucu oluşan künt karın travmasına bağlı pnömobili gelişen ve medikal tedavi uygulanan olgu sunuldu.

Anahtar Sözcükler: Karın; künt travma; pnömobili.
Pneumobilia is described as the presence of gas in the biliary system due to an abnormal connection between the gastrointestinal tract and biliary tract. The most common causes of pneumobilia are biliaryenteric surgical anastomosis, incompetent sphincter of Oddi or spontaneous biliary-enteric fistula. ${ }^{[1]}$ In the absence of a surgically created anastomosis, the finding has been considered as an indication of the need for surgical exploration. Pneumobilia has also been reported following blunt abdominal trauma, but only rarely. ${ }^{[2,3]}$

In this report, we present an elderly female patient who had been struck by a motor vehicle and was found to have massive pneumobilia on computed tomographic (CT) scan of the abdomen, which healed without operative management.

\section{CASE REPORT}

A 61-year-old female was transferred from a community hospital to our center, Harran University
Medical Faculty, Department of General Surgery after being struck by a motor vehicle. After initial evaluation at the community hospital, pneumobilia was demonstrated by CT scan of the abdomen. The patient was then transferred to Harran University Medical Faculty. She remained hemodynamically stable during transport. On admission, the patient was awake and conscious. She had multiple abrasions and contusions on examination. She was slightly tender over the right upper quadrant of the abdomen. Medical and surgical histories were insignificant. Hematological and biochemical investigations were all normal. Ultrasonography and CT scan detected pneumobilia (Figs. 1, 2). There were no other pathological findings. The patient was subsequently admitted to our clinic, where she was managed with bed rest, broad-spectrum antibiotic coverage and repeated clinical evaluations and leukocyte counts. This patient remained stable. Her total hospital stay was seven days, and she was discharged with analgesics.
Departments of ${ }^{1}$ General Surgery, ${ }^{3}$ Radiology, Harran University Faculty of Medicine, Şanliurfa; ${ }^{2}$ Department of General Surgery, Gaziantep University Faculty of Medicine, Gaziantep, Turkey.
Harran Üniversitesi Tıp Fakültesi, ${ }^{1}$ Genel Cerrahi Anabilim Dalı, ${ }^{3}$ Radyoloji Anabilim Dalı, Şanlıurfa; ${ }^{2}$ Gaziantep Üniversitesi Tıp Fakültesi, Genel Cerrahi Anabilim Dalı, Gaziantep. 


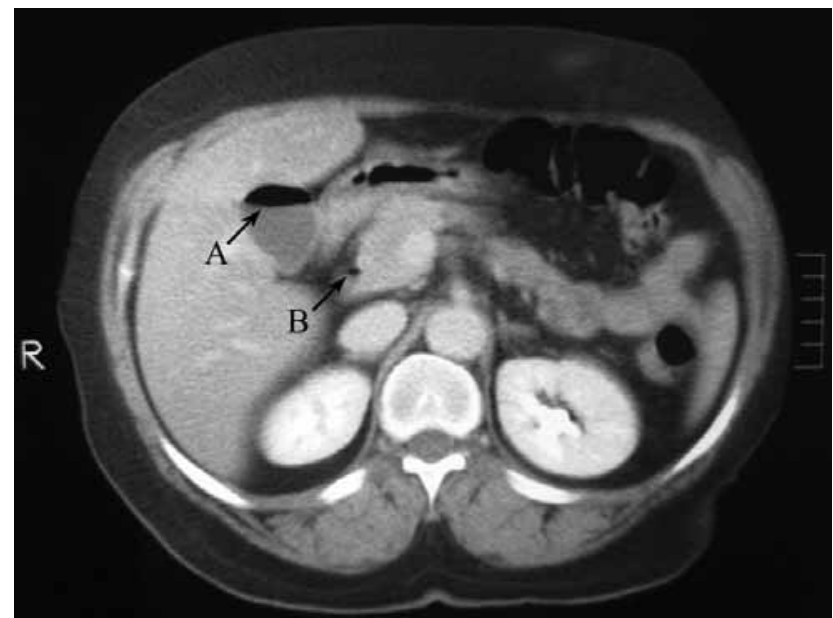

Fig. 1. Air seen in gallbladder (A) and common bile duct (B).

\section{DISCUSSION}

Pneumobilia is mainly caused by spontaneous biliary-enteric fistula secondary to gallstone erosion through the gallbladder wall to an adjacent viscus. ${ }^{[1]}$ Other well-documented causes of pneumobilia are instrumentation of the bile duct on endoscopic retrograde cholangiopancreatography and surgically created anastomosis between the biliary tract and the bowel. ${ }^{[2]}$ Emphysematous cholecystitis has also been reported as a cause of pneumobilia, but it is very rare. ${ }^{[4]}$ Pneumobilia can also occur following blunt abdominal trauma, ${ }^{[3,5]}$ but to date no more than five cases of such injury have been reported in the literature.

The patient, who presented with pneumobilia, had no history of gallstones, right upper quadrant pain or surgery. In addition, the abdominal ultrasound and CT scan did not reveal evidence of gallstones. Therefore, in this patient, gallstone disease was unlikely to be the cause of the pneumobilia.

The cause of this patient's pneumobilia was unclear. She had no surgery, endoscopy, gallbladder disease, or gallstones. In this case, we thought that the increase in pressure within the duodenum due to the blunt abdominal trauma forced air into the biliary tree

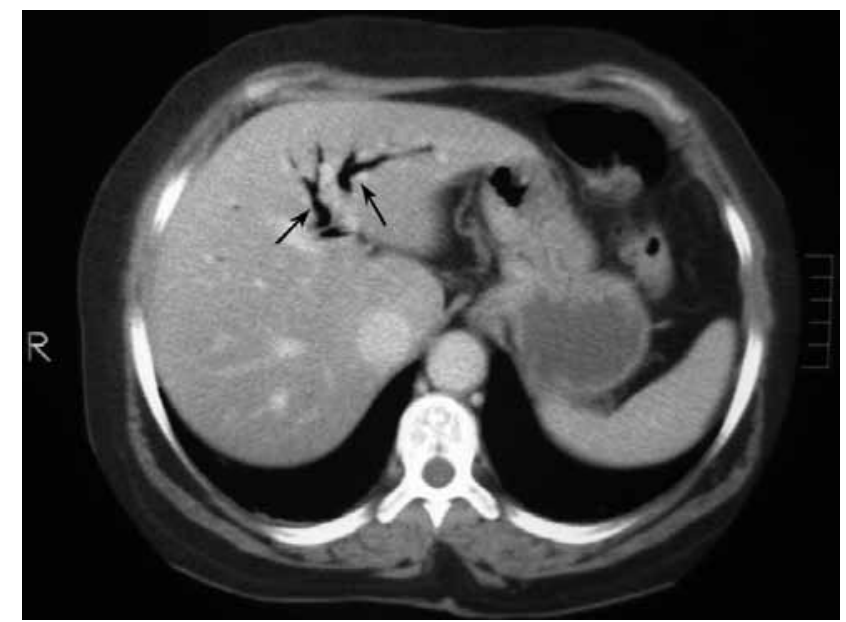

Fig. 2. Air seen in the left intrahepatic biliary duct (black arrowhead).

through the sphincter of Oddi, causing the pneumobilia. In addition, it is possible that an incompetent or dysfunctional sphincter of Oddi may have let air in the duodenum pass into the biliary tree. Pneumobilia identified in our patient was without an intra-abdominal injury requiring surgery.

In conclusion, we can say that pneumobilia may be caused by blunt abdominal trauma, but it does not always necessarily indicate a need for surgical exploration.

\section{REFERENCES}

1. Yamashita H, Chijiiwa K, Ogawa Y, Kuroki S, Tanaka M. The internal biliary fistula--reappraisal of incidence, type, diagnosis and management of 33 consecutive cases. HPB Surg 1997;10:143-7.

2. Ladurner R, Kotsianos D, Mutschler W, Mussack T. Traumatic pneumobilia after cardiopulmonary resuscitation. Eur J Med Res 2005;10:495-7.

3. Ohtani Y, Tanaka Y, Tsukui M, Goto K, Moriya H, Tobita K, et al. Acute emphysematous cholecystitis associated with pneumobilia: a case report. Tokai J Exp Clin Med 1996;21:33-6.

4. Thompson RJ, Irwin T. Pneumobilia following blunt abdominal trauma. Ir J Med Sci 2007;176:313-5.

5. Gering SA, Foster MA, Harnisch MC, McNeil JJ. Traumatic pneumobilia: case report. J Trauma 2001;51:391-4. 